\title{
Faecal bile acid excretion in children with inflammatory bowel disease
}

\author{
J Ejderhamn, J J Rafter, B Strandvik
}

\begin{abstract}
Faecal bile acid excretion and intestinal transit time were studied in 18 children with inflammatory bowel disease in clinical remission and with normal stools: 16 with ulcerative colitis, two with Crohn's colitis, mean age 14 years (range 10-17 years). Five healthy children, mean age 12.4 years (range 10-17 years), were studied as control subjects. Most patients were taking sulphasalazine, but none were taking steroids. Transit time was determined by carmine and did not differ between groups. Faeces were collected for $\mathbf{7 2}$ hours, and faecal water was prepared by centrifugation of faeces at $15000 \times \mathrm{g}$ for two hours. Bile acids in total faeces and faecal water were studied using capillary gas-liquid chromatography-mass spectrometry. Faecal excretion of total bile acids, unconjugated bile acids, and glycine and taurine conjugates were significantly increased in patients as was faecal water excretion of total bile acids, particularly the taurine conjugates and cholic and chenodeoxycholic acids. Total concentrations of bile acids in faeces and faecal water were two to five times higher in patients. The children with inflammatory bowel disease in clinical remission had high excretion and concentration rates of bile acids, especially taurine conjugates, in both total faeces and faecal water, a finding of considerable interest in the pathogenesis of malignancy in these diseases.
\end{abstract}

Many studies support the hypothesis that faecal bile acids play a part in the pathogenesis of colonic cancer. ${ }^{1-5}$ More recently, increased concentrations of soluble faecal bile acids have been suggested as a risk factor in colonic carcinogenesis. ${ }^{67}$ Patients with a long duration of inflammatory bowel disease and total colitis are known to run a high risk of developing colonic cancer even when in remission. ${ }^{8-10}$ It has been suggested that high concentrations of faecal bile acids are associated with dysplasia and carcinoma in ulcerative colitis. " Conservative treatment of inflammatory bowel disease in children has in many cases a beneficial effect and causes remission of severe symptoms, but duration of disease or genetic factors, or both, have been considered a major risk factor for colonic cancer, ${ }^{812}$ suggesting that factors present during remission might be important. The remission phase of the disease will be important in the long term for the risk of developing colonic cancer, since if the patient does not remain in remission or has a severe disease which does not respond to medical treatment a colectomy will be performed. The aim of our study was to investigate the concentration and composition of bile acids in total faeces and in the aqueous fraction - that is, the faecal water - in children with inflammatory bowel disease during clinical remission.

\section{Patients}

Eighteen children with inflammatory bowel disease, mean age of 14 years (range 10-17 years), were studied. The diagnosis of inflammatory bowel disease was based on generally accepted criteria. ${ }^{1314}$ Twelve had ulcerative colitis of the total colon, in four it affected the distal colon only, and two had Crohn's colitis including involvement of the small intestine in one (ileum). The average duration of inflammatory bowel disease was $2 \cdot 7$ years (range $0.5-5$ years). Almost all patients were taking sulphasalazine and none were taking steroid drugs. The patients had been off local steroid treatment for at least three months before entering the study. Stools were well formed in all patients except four, whose stools were slightly less formed but not watery. The mean frequency of stools was $1 \cdot 5 /$ day (range 1-3). The patients were in good clinical condition and biochemical markers of inflammation were normal: mean (SEM) erythrocyte sedimentation rate was $5(1 \cdot 2) \mathrm{mm}$ in the 1st hour and serum concentration of orosomucoid $0 \cdot 6(0 \cdot 1) \mathrm{g} / \mathrm{l}$ (reference values being $1-20$ $\mathrm{mm}$ in the 1 st hour and $0 \cdot 3-1.0 \mathrm{~g} / \mathrm{l}$, respectively).

Five healthy children of the medical staff acted as controls, their mean age being 12.4 years (range 10-17 years) and all had normal stools.

\section{Methods}

Faeces were collected over 72 hours and frozen at $-20^{\circ} \mathrm{C}$ until analysis. The samples from each patient were pooled, mixed, and homogenised using a Stomacher Lab Blender 3500 and divided into aliquots for analysis of total bile acids and bile acids in the aqueous phase.

ANALYSIS OF TOTAL BILE ACIDS

Analysis of total bile acids was performed according to Breuer $e t$ al ${ }^{15}$ with slight modification. Some $2 \cdot 5-3 \mathrm{~g}$ faeces were lyophilised and bile acids and neutral sterols extracted by sequential refluxing in organic solvents. The extracts were then purified and the bile acids separated according to Almé $e t$ a $l^{16}$ into unconjugated, glycine conjugated, taurine conjugated, and sulphated bile acids. Glycine, taurine, and sulphated effluents were lyophilised. After enzymatic solvolysis and hydrolysis according to Hedenborg and Norman, ${ }^{17}$ the bile acids were converted to methyl esters using fresh diazomethane and further derivatised to trimethylsilyl ethers. ${ }^{16}$ Since coprostanol was eluted in the 
TABLE I Total faecal and faecal water excretion rate (mg/day) of unconjugated, glycine conjugated, taurine conjugated, and sulphated bile acids and cholic acid, chenodeoxycholic acid, deoxycholic acid, and lithocholic acid in inflammatory bowel disease patients $(n=18)$ and healthy control children $(n=5)$

\begin{tabular}{|c|c|c|c|c|}
\hline \multirow[b]{2}{*}{ Bile acids } & \multicolumn{2}{|l|}{ Faeces } & \multicolumn{2}{|l|}{ Faecal water } \\
\hline & Patients & Control subjects & Patients & Control subjects \\
\hline \multicolumn{5}{|l|}{ Unconjugated } \\
\hline Mean & $159 \cdot 9 \star$ & $68 \cdot 1$ & $10 \cdot 4^{\star}$ & $2 \cdot 1$ \\
\hline Median (range) & $136(34 \cdot 2-431 \cdot 4)$ & $83.9(47 \cdot 3-98)$ & $5 \cdot 6(1 \cdot 0-43)$ & $2 \cdot 3(0.7-4.4)$ \\
\hline \multicolumn{5}{|l|}{ Glycine conjugated } \\
\hline Mean & $3 \cdot 2^{\star}$ & 0.4 & $0 \cdot 2$ & 0.06 \\
\hline Median (range) & $2 \cdot 0(0 \cdot 4-17 \cdot 2)$ & $0 \cdot 3(0 \cdot 1-1 \cdot 0)$ & $0.1(0.01-0.9)$ & $0.05(0.03-0.1)$ \\
\hline \multicolumn{5}{|l|}{ Taurine conjugated } \\
\hline Mean & $30.8 t$ & $1 \cdot 3$ & $0 \cdot 6 \dagger$ & 0.003 \\
\hline Median (range) & $17 \cdot 9(2-185 \cdot 3)$ & $0.7(0.3-2 \cdot 7)$ & $0.3(0.02-4 \cdot 6)$ & $0.003(0.0-0.01)$ \\
\hline \multicolumn{5}{|l|}{ Sulphated } \\
\hline Mean & $2 \cdot 1$ & 0.9 & $0 \cdot 2$ & 0.01 \\
\hline Median (range) & $0.9(0 \cdot 1-11 \cdot 7)$ & $0 \cdot 4(0 \cdot 2-3 \cdot 1)$ & $0.02(0.003-2.5)$ & $0.01(0.004-0.02)$ \\
\hline \multicolumn{5}{|l|}{ Cholic acid } \\
\hline Mean & 48.9 & 1.6 & $5 \cdot 7^{\star}$ & $0 \cdot 1$ \\
\hline Median (range) & $7 \cdot 2(0 \cdot 1-286)$ & $1 \cdot 0(0 \cdot 2-3 \cdot 6)$ & $1 \cdot 1(0 \cdot 02-32)$ & $0 \cdot 1(0 \cdot 01-0 \cdot 3)$ \\
\hline \multicolumn{5}{|c|}{ Chenodeoxycholic acid } \\
\hline Mean & $27 \cdot 7$ & $1 \cdot 3$ & $0 \cdot 8^{\star}$ & 0.03 \\
\hline Median (range) & $10 \cdot 1(0 \cdot 4-160 \cdot 1)$ & $1 \cdot 3(0.5-1.9)$ & $0 \cdot 2(0.002-4 \cdot 5)$ & $0.04(0.004-0.09)$ \\
\hline \multicolumn{5}{|l|}{ Deoxycholic acid } \\
\hline Mean & $43 \cdot 9$ & $20 \cdot 3$ & 1.8 & 0.7 \\
\hline Median (range) & $32 \cdot 4(1 \cdot 7-103 \cdot 6)$ & $18 \cdot 1(3 \cdot 5-46 \cdot 3)$ & $1 \cdot 5(0 \cdot 1-7 \cdot 1)$ & $0.5(0 \cdot 1-1 \cdot 6)$ \\
\hline \multicolumn{5}{|l|}{ Lithocholic acid } \\
\hline Mean & $37 \cdot 8$ & $31 \cdot 4$ & 0.3 & 0.5 \\
\hline Median (range) & $35 \cdot 0(0 \cdot 4-155 \cdot 6)$ & $32 \cdot 9(14 \cdot 5-44)$ & $0 \cdot 2(0 \cdot 0-2 \cdot 0)$ & $0.4(0.3-0.8)$ \\
\hline
\end{tabular}

Significance levels compared with respective controls ${ }^{\star} \mathrm{p}<0.05, \mathrm{tp}<0.01$.

neutral fraction before the unconjugated bile acids (data not shown), coprostanol was used as the internal standard. Isolation and quantitation of bile acids were performed by gas-liquid chromatography (HP 5830) using splitless injection on an $18 \mathrm{~m}$ capillary column (OV-101). Helium was used as the carrier gas and the flow rate was $2 \mathrm{ml} / \mathrm{min}$. A temperature programmed operation from $50^{\circ} \mathrm{C}$ to $200^{\circ} \mathrm{C}$ in 4 minutes was used, followed by an increase to $266^{\circ} \mathrm{C}$ at $5^{\circ} \mathrm{C} /$ $\mathrm{min}$ and then an isothermal period of 60 minutes. Injection temperature was $325^{\circ} \mathrm{C}$ and the temperature at the detector was $250^{\circ} \mathrm{C}$. Identification was carried out by gas chromatography-mass spectrometry, using the same chromatographic conditions as in the gas-liquid chromatography analyses. An LKB 2091 instrument with a dual jet separator was used. The energy of the bombarding electrons was $22.5 \mathrm{eV}$. Quantitation of individual bile acids was achieved by computerised integration of peak areas and a comparison with known amounts of internal standards and the response factor of standard bile acids. The separation of bile acid conjugates was checked by thin layer chromatography according to Gänshirt et al. ${ }^{18}$

\section{SOLUBLE BILE ACIDS}

Preparation of faecal water was performed by centrifugation of faeces at $15000 \times g$ for 2 hours at $20^{\circ} \mathrm{C}$ in a Sorvall ultracentrifuge. ${ }^{19}$ Centrifugation at a higher $g$ or for a longer time did not give higher yields (data not shown). The supernatant was decanted and then frozen at $-20^{\circ} \mathrm{C}$ until the analyses were performed. Analysis of bile acids in faecal water followed the same procedure as for total faecal bile acids but started with passage through a Sep-pak C18 cartridge.

TRANSIT TIME

The transit time of carmine was estimated at the time of faeces collection by giving each child
$0.5 \mathrm{~g}$ carmine orally and noting when the stools changed colour. ${ }^{20}$

\section{STATISTICS}

The Mann-Whitney $U$ test and Wilcoxon matched pairs signed rank test were used for statistical analyses. Variation was indicated by standard error of the mean (SEM) if not otherwise indicated.

The study was approved by the local ethical committee of Karolinska Institutet and informed consent was obtained from parents and patients.

\section{Results \\ EXCRETION RATE OF BILE ACIDS}

\section{Faeces}

The mean (SEM) total bile acid excretion rate in the patients with inflammatory bowel disease (196.1 (34) $\mathrm{mg} /$ day) compared with control subjects $(70 \cdot 7(14.6) \mathrm{mg} /$ day) was significantly increased $(p<0.05)$. Unconjugated bile acids predominated in faeces in both patients and control subjects. The daily faecal excretion (mean (SEM)) of unconjugated $(159.9(25.8) \mathrm{mg} /$ day) and glycine $(3.2(0.9) \mathrm{mg} /$ day) and taurine $(30.8(9.9) \mathrm{mg} /$ day $)$ conjugated bile acids was significantly increased $(\mathrm{p}<0.05, \mathrm{p}<0.05$, and $\mathrm{p}<0.01$, respectively) in the patients compared with the control subjects $(68 \cdot 1(14 \cdot 4), 0.4(0.2)$, and $1.3(0.5) \mathrm{mg} /$ day, respectively) (Table I). Sulphated bile acids accounted for a minor part in both groups of children. The secondary bile acids, deoxycholic and lithocholic acids, predominated in healthy children, but excretion was only slightly greater than the primary bile.acids, cholic and chenodeoxycholic acids, in patients (Table I).

\section{Faecal water}

The daily faecal water excretion (mean (SEM)) of total bile acids in patients $(11.5(3.2) \mathrm{mg} /$ day) was significantly increased compared with control subjects $(2.2(0.7) \mathrm{mg} /$ day $)(\mathrm{p}<0.05)$, and unconjugated and taurine conjugated bile acids were significantly increased in patients compared with control subjects $(p<0.05$ and $\mathrm{p}<0 \cdot 01$, respectively) (Table I). The primary bile acids, cholic and chenodeoxycholic acids, were each excreted in faecal water in significantly higher amounts in patients than in control subjects ( $p<0.05$, respectively) (Table I).

\section{CONCENTRATION OF BILE ACIDS}

\section{Faeces}

In patients the concentration of total bile acids in faeces (Fig 1) as well as the faecal concentrations of unconjugated and glycine and taurine conjugated bile acids were significantly increased compared with control subjects as were the concentrations of cholic and chenodeoxycholic acids (Table II). In addition, the concentration of deoxycholic acid in dried faeces was significantly higher in patients than in control subjects. 

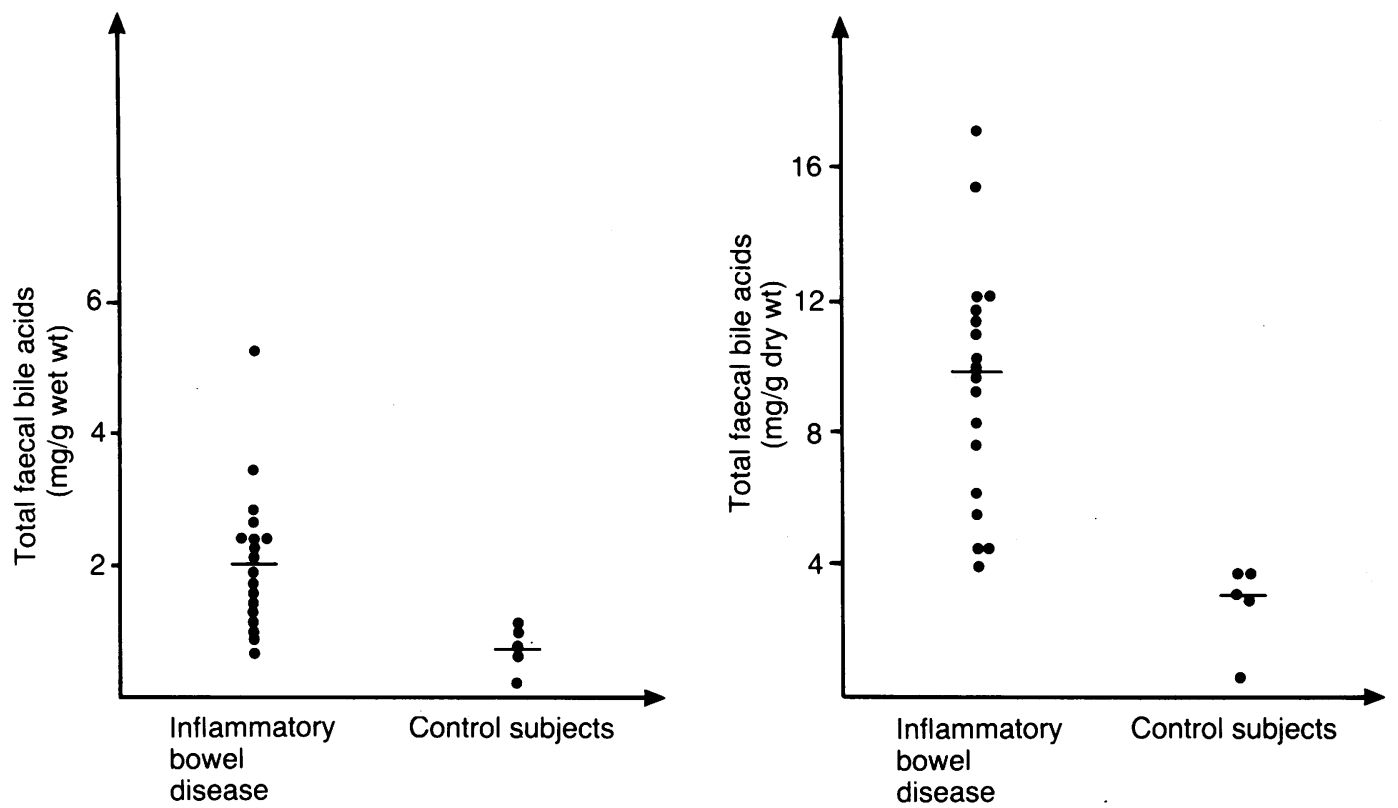

Figure 1: Concentrations of total faecal bile acids in faeces in children with inflammatory bowel disease and control children. Median values are indicated by lines.

Faecal water

A similar pattern was found in faecal water with significantly higher concentrations of total bile acids in faecal water in patients compared with control subjects (Fig 2). The concentrations of soluble unconjugated, glycine and taurine conjugated, and sulphated bile acids as well as that of cholic, chenodeoxycholic, and deoxycholic acids were significantly increased in the faecal water of patients compared with control subjects (Table III). In faecal water as well as in faeces, a pronounced increase was seen in taurine conjugated bile acids (Tables II and III).

\section{PERCENTAGE DISTRIBUTION OF BILE ACIDS}

\section{Faeces}

The percentage distribution of conjugates showed significantly higher fractions of taurine conjugated bile acids in patients compared with control subjects $(p<0.05)$. There was a tendency to higher percentages of primary bile acids in concordance with a significantly smaller fraction of lithocolic acid in patients $(\mathrm{p}<0.05)$ (Table II). The ratio of glycine to taurine conjugated bile acids did not differ between patients and control subjects (Table IV).

\section{Faecal water}

The pattern in faecal water was similar to that in faeces with a significantly higher fraction of taurine conjugated bile acids and a significantly smaller percentage of lithocholic acid in patients compared with control subjects $(\mathrm{p}<0.01$ and $\mathrm{p}<0.05$, respectively). The ratio of glycine to taurine conjugated bile acids in the soluble phase was significantly lower in patients compared with controls $(\mathrm{p}<0.01)$ (Table IV). Moreover, the glycine-taurine ratio was only increased three to fivefold in faecal water compared with total faeces in the patients $(p<0.01)$, the corresponding increase being 20 to 40 -fold in the control subjects (NS).
PERCENTAGE SOLUBLE BILE ACIDS

There was a non-significant higher fraction of soluble faecal bile acids in patients than in control subjects, $6 \% v 3 \%$ (Table V). Unconjugated, glycine conjugated, and sulphated bile acids showed a similar distribution in patients and control subjects, but taurine conjugated bile acids were significantly increased in the soluble fraction in the patients $(\mathrm{p}<0.01)$. Primary bile acids were present in higher concentrations in faecal water, soluble cholic and chenodeoxycholic acids showing four to sevenfold higher levels in patients than in control subjects (not significant, respectively). Deoxycholic acid showed a similar distribution in the two groups and the lithocholic acid was less in the soluble fraction in the patients $(\mathrm{p}<0.05)($ Table $\mathrm{V})$.

TABLE II Mean $(S D)$ faecal concentration of unconjugated, glycine conjugated, taurine conjugated, and sulphated bile acids and cholic acid, chenodeoxycholic acid, deoxycholic acid, and lithocholic acid in inflammatory bowel disease patients $(n=18)$ and healthy control children $(n=5)$

\begin{tabular}{|c|c|c|}
\hline Bile acids & Patients & Control subjects \\
\hline $\begin{array}{l}\text { Unconjugated } \\
\mathrm{mg} / \mathrm{g} \text { wet faeces } \\
\mathrm{mg} / \mathrm{g} \text { dry faeces }\end{array}$ & $\begin{array}{l}1 \cdot 7(0 \cdot 8)^{\star} \\
8 \cdot 7(3 \cdot 2) \dagger\end{array}$ & $\begin{array}{l}0.7(0.3) \\
2 \cdot 8(1 \cdot 3)\end{array}$ \\
\hline $\begin{array}{l}\text { Glycine conjugated } \\
\mathrm{mg} / \mathrm{g} \text { wet faeces } \\
\mathrm{mg} / \mathrm{g} \text { dry faeces }\end{array}$ & $\begin{array}{l}0.03(0.04)^{\star} \\
0.15(0.1)^{\circ}\end{array}$ & $\begin{array}{l}0.005(0.005) \\
0.02(0.02)\end{array}$ \\
\hline $\begin{array}{l}\text { Taurine conjugated } \\
\mathrm{mg} / \mathrm{g} \text { wet faeces } \\
\mathrm{mg} / \mathrm{g} \text { dry faeces }\end{array}$ & $\begin{array}{l}0 \cdot 3(0 \cdot 3) \dagger \\
1 \cdot 4(1 \cdot 1) \dagger\end{array}$ & $\begin{array}{l}0.01(0.01) \\
0.05(0.04)\end{array}$ \\
\hline $\begin{array}{l}\text { Sulphated } \\
\text { mg/g wet faeces } \\
\text { mg/g dry faeces } \\
\text { Cholic acid }\end{array}$ & $\begin{array}{l}0 \cdot 02(0: 02) \\
0 \cdot 1(0 \cdot 1)\end{array}$ & $\begin{array}{l}0.01(0.02) \\
0.05(0.08)\end{array}$ \\
\hline $\begin{array}{l}\text { Cholic acid } \\
\mathrm{mg} / \mathrm{g} \text { wet faeces } \\
\mathrm{mg} / \mathrm{g} \text { dry faeces }\end{array}$ & $\begin{array}{l}0.3(0.5)^{\star} \\
1.8(2.6)^{\star}\end{array}$ & $\begin{array}{l}0.02(0.01) \\
0.07(0.05)\end{array}$ \\
\hline $\begin{array}{l}\text { Chenodeoxycholic acid } \\
\mathrm{mg} / \mathrm{g} \text { wet faeces } \\
\mathrm{mg} / \mathrm{g} \text { dry faeces }\end{array}$ & $\begin{array}{l}0 \cdot 2(0 \cdot 2)^{\star} \\
0 \cdot 9(1 \cdot 1)^{\star}\end{array}$ & $\begin{array}{l}0.01(0.005) \\
0.05(0.02)\end{array}$ \\
\hline $\begin{array}{l}\text { Deoxycholic acid } \\
\mathrm{mg} / \mathrm{g} \text { wet faeces } \\
\mathrm{mg} / \mathrm{g} \text { dry faeces }\end{array}$ & $\begin{array}{l}0 \cdot 6(0 \cdot 6) \\
2 \cdot 8(2 \cdot 1)^{\star}\end{array}$ & $\begin{array}{l}0.2(0.2) \\
0 \cdot 8(0 \cdot 6)\end{array}$ \\
\hline $\begin{array}{l}\text { Lithocholic acid } \\
\mathrm{mg} / \mathrm{g} \text { wet faeces } \\
\mathrm{mg} / \mathrm{g} \text { dry faeces }\end{array}$ & $\begin{array}{l}0.5(0.4) \\
2 \cdot 2(1.5)\end{array}$ & $\begin{array}{l}0.3(0.1) \\
1 \cdot 3(0.5)\end{array}$ \\
\hline
\end{tabular}

Significance levels compared with respective controls ${ }^{\star} p<0.05$ tp $<0.01$. 

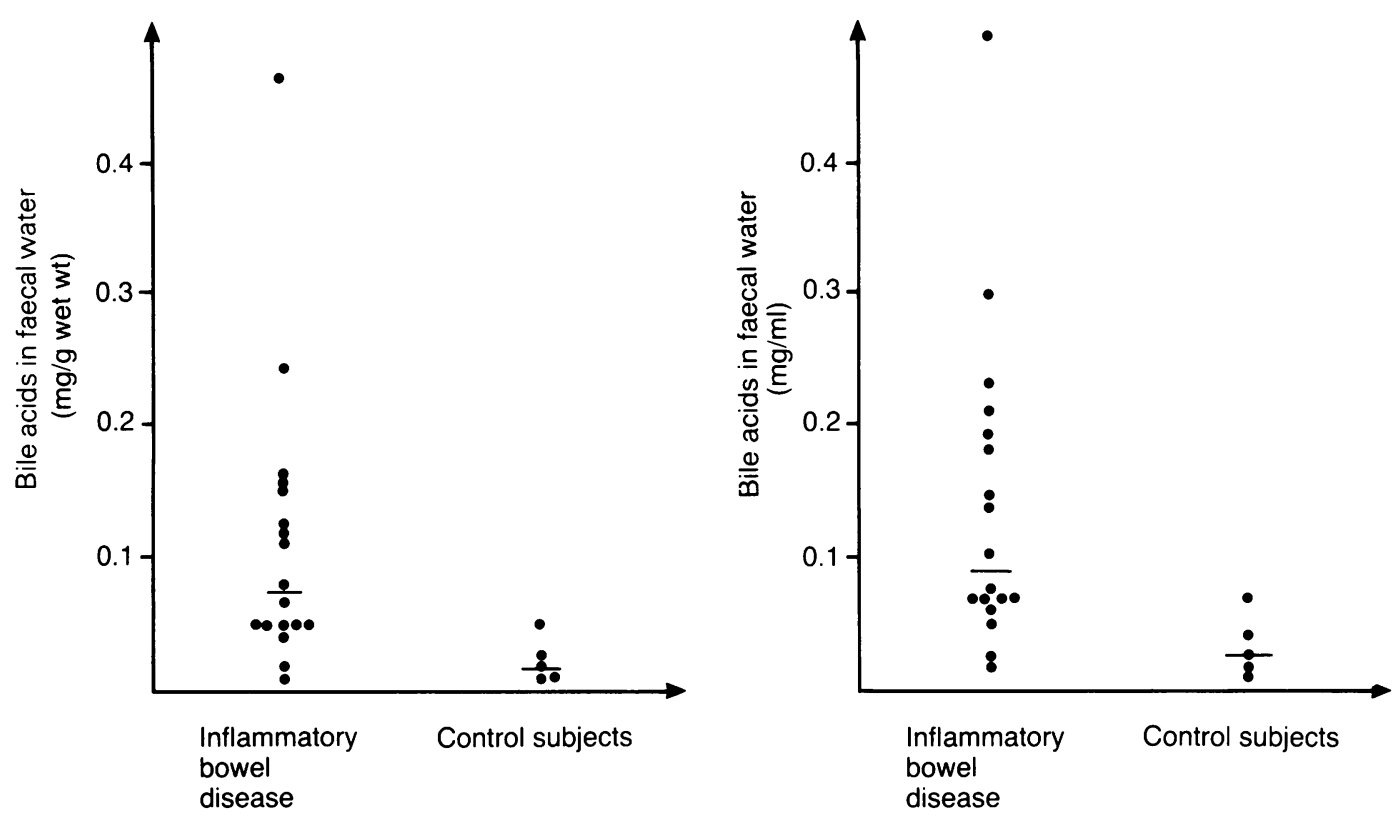

Figure 2: Concentration of bile acids in faecal water in children with inflammatory bowel disease and in control children. Median values are indicated by lines.

\section{TRANSIT TIME}

There were no significant differences in the transit times of carmine between the patients and the control subjects, the mean (SD) being $2 \cdot 1$ $(0 \cdot 8)$ and $2 \cdot 0(0 \cdot 7)$ days, respectively.

\section{Discussion}

The faecal bile acid concentration in the healthy control children corresponded to that found in earlier reports from adults, although the children had smaller fractions of primary bile acids (mean $4 \cdot 6 \%$, range $1 \cdot 6-6 \cdot 6 \%$ ) and sulphated bile acids (mean $1 \cdot 8 \%$, range $0 \cdot 2-6 \cdot 1 \%$ ). Breuer et $a l^{15}$ reported that these fractions were $10.4 \%$ and $4 \cdot 4 \%$, respectively in adults. Both in faeces and

TABLE III Mean (SD) faecal water concentration of unconjugated, glycine conjugated, taurine conjugated, and sulphated bile acids and cholic acid, chenodeoxycholic acid, deoxycholic acid, and lithocholic acid in inflammatory bowe disease patients $(n=18)$ and healthy control children $(n=5)$

\begin{tabular}{|c|c|c|}
\hline Bile acids & Patients & Control subjects \\
\hline $\begin{array}{l}\text { Unconjugated } \\
\mathrm{mg} / \mathrm{g} \text { wet faeces } \\
\mathrm{mg} / \mathrm{ml} \text { faecal water }\end{array}$ & $\begin{array}{l}0 \cdot 1(0 \cdot 1)^{\star} \\
0 \cdot 1(0 \cdot 1)^{\star}\end{array}$ & $\begin{array}{l}0.02(0.02) \\
0.03(0.02)\end{array}$ \\
\hline $\begin{array}{l}\text { Glycine conjugated } \\
\mathrm{mg} / \mathrm{g} \text { wet faeces } \\
\mathrm{mg} / \mathrm{ml} \text { faecal water }\end{array}$ & $\begin{array}{l}0.002(0.002)^{\star} \\
0.003(0.003)^{\star}\end{array}$ & $\begin{array}{l}0.0006(0.0003) \\
0.001(0.001)\end{array}$ \\
\hline $\begin{array}{l}\text { Taurine conjugated } \\
\mathrm{mg} / \mathrm{g} \text { wet faeces } \\
\mathrm{mg} / \mathrm{ml} \text { faecal water }\end{array}$ & $\begin{array}{l}0.006(0.007) \dagger \\
0.007(0.009) \dagger\end{array}$ & $\begin{array}{l}0.00004(0.00004) \\
0.0001(0.0001)\end{array}$ \\
\hline $\begin{array}{l}\text { Sulphated } \\
\mathrm{mg} / \mathrm{g} \text { wet faeces } \\
\mathrm{mg} / \mathrm{ml} \text { faecal water }\end{array}$ & $\begin{array}{l}0.002(0.003)^{\star} \\
0.002(0.004)^{\star}\end{array}$ & $\begin{array}{l}0.0001(0.0001) \\
0.0001(0.0001)\end{array}$ \\
\hline $\begin{array}{l}\text { Cholic acid } \\
\mathrm{mg} / \mathrm{g} \text { wet faeces } \\
\mathrm{mg} / \mathrm{ml} \text { faecal water }\end{array}$ & $\begin{array}{l}0.04(0.07)^{\star} \\
0.06(0.08)^{\star}\end{array}$ & $\begin{array}{l}0.001(0.001) \\
0.002(0.001)\end{array}$ \\
\hline $\begin{array}{l}\text { Chenodeoxycholic acid } \\
\mathrm{mg} / \mathrm{g} \text { wet faeces } \\
\mathrm{mg} / \mathrm{ml} \text { faecal water }\end{array}$ & $\begin{array}{l}0.005(0.006)^{\star} \\
0.006(0.007)^{\star}\end{array}$ & $\begin{array}{l}0.0004(0.0004) \\
0.0004(0.0004)\end{array}$ \\
\hline $\begin{array}{l}\text { Deoxycholic acid } \\
\mathrm{mg} / \mathrm{g} \text { wet faeces } \\
\mathrm{mg} / \mathrm{ml} \text { faecal water }\end{array}$ & $\begin{array}{l}0.02(0.02)^{\star} \\
0.03(0.03)^{\star}\end{array}$ & $\begin{array}{l}0.007(0.006) \\
0.009(0.009)\end{array}$ \\
\hline $\begin{array}{l}\text { Lithocholic acid } \\
\mathrm{mg} / \mathrm{g} \text { wet faeces } \\
\mathrm{mg} / \mathrm{ml} \text { faecal water }\end{array}$ & $\begin{array}{l}0.006(0.01) \\
0.008(0.02)\end{array}$ & $\begin{array}{l}0.005(0.002) \\
0.006(0.003)\end{array}$ \\
\hline
\end{tabular}

Significance levels compared with respective controls ${ }^{\star} p<0 \cdot 05$, $t \mathrm{p}<0 \cdot 01$. in faecal water the patients with inflammatory bowel disease had significantly higher concentrations of cholic and deoxycholic acids than chenodeoxycholic and lithocholic acids. A similar trend was seen in the faecal water from control subjects but not in the total faecal bile acid concentration, where chenodeoxycholic acid and its transformation product lithocholic acid predominated in the healthy children (Tables II and III). This might indicate differences in bile acid synthesis or absorption - that is, differences in the metabolism within the enterohepatic circulation in patients with inflammatory bowel disease.

In contrast to the findings in the healthy subjects, the fraction of glycine conjugates was smaller than that of taurine conjugates in faecal water from patients. The mean total concentrations of bile acids in faeces and faecal water were approximately two to five times higher in the patients than in the control subjects $(\mathrm{p}<0.01$ and $\mathrm{p}<0.05$, respectively), although the patients were in remission. This was unexpected, since only active inflammatory bowel disease has been found previously to be associated with increases in faecal bile acid concentrations. ${ }^{21}$ Thus although the patients were in good clinical condition with normal stools and normal transit times of carmine, they had high faecal concentrations of bile acids including the soluble fraction. Bile acid malabsorption has been reported in patients who were asymptomatic or had mild disease activity, but colonoscopy showed that many of these patients had a high degree of inflammation in the mucosa of the right colon. ${ }^{22}$ Our findings are of interest with regard to the suggestion that bile acids are a factor in the risk of developing colonic cancer. ${ }^{1123}$ The fact that our patients had significantly higher concentrations of soluble bile acids in their faeces is also of considerable interest in light of recent data which indicate that it may be the soluble fraction of the faecal bile acids rather than the total concentration which constitutes the real risk for colonic 
TABLE IV Ratio of glycine $(G)$ to taurine $(T)$ conjugated bile acids expressed as percentage in faeces and faecal water of patients with inflammatory bowel disease $(n=18)$ and healthy age matched children $(n=5)$

\begin{tabular}{|c|c|c|c|}
\hline & \multicolumn{2}{|l|}{ Ratio $G / T$} & \multirow[b]{2}{*}{$p^{\star}$} \\
\hline & Patients & Control subjects & \\
\hline $\begin{array}{l}\text { Faeces } \\
\text { Mean } \\
\text { Median (range) }\end{array}$ & $\begin{array}{l}20 \\
10(2-141)\end{array}$ & $\begin{array}{l}90 \\
33(6-367)\end{array}$ & $\begin{array}{l}\text { Not } \\
\text { significant }\end{array}$ \\
\hline $\begin{array}{l}\text { Faecal water } \\
\text { Mean } \\
\text { Median (range) }\end{array}$ & $\begin{array}{l}80 \\
50(7-391)\end{array}$ & $\begin{array}{l}1610 \\
1310(708-1790)\end{array}$ & $<0.01$ \\
\hline
\end{tabular}

*Significance compared with controls.

cancer. ${ }^{67}$ Soluble bile acids are toxic and can induce cell proliferation in colons of experimental animals. ${ }^{24}{ }^{25}$ In a recent study the aqueous phase of faeces (faecal water) from patients with colonic tumours contained significantly higher concentrations of secondary bile acids than that from healthy control subjects. ${ }^{23}$ The high concentrations of deoxycholic acid in the faeces of the patients in our study are also interesting since it has been suggested that the high concentrations of secondary bile acids in the bile acid pool and in faeces after cholecystectomy ${ }^{26-28}$ might be a risk factor for colonic malignancy, ${ }^{29}$ thus indicating that cholecystectomy may be a predisposing factor for the development of colorectal cancer. . $^{30-32}$

The most interesting finding was the significantly increased faecal excretion of taurine conjugates in the patients in clinical remission, which to the best of our knowledge has not been reported before. In addition, the faecal water excretion of total bile acids and particularly the taurine conjugates was increased in the patients. This is in line with the observation of Tanida $e t$ $a l,{ }^{21}$ who found high concentrations of taurine conjugated bile acids in faeces and also in faecal water in patients with inflammatory bowel

TABLE V Percentage soluble bile acids recovered in faecal water of the total faecal bile acids in patients with

inflammatory bowel disease $(n=18)$ and healthy age matched control children $(n=5)$

\begin{tabular}{|c|c|c|}
\hline \multirow[b]{2}{*}{ Soluble bile acids } & \multicolumn{2}{|c|}{$\begin{array}{l}\text { Ratio: soluble bile acids/total faecal bile } \\
\text { acids }\end{array}$} \\
\hline & Patients & Control subjects \\
\hline \multicolumn{3}{|l|}{ Total bile acids } \\
\hline Mean & 6 & 3 \\
\hline \multicolumn{3}{|l|}{ Unconjugated } \\
\hline Mean & 5 & \\
\hline Median (range) & $5(0 \cdot 8-12 \cdot 6)$ & $3(1 \cdot 4-4 \cdot 3)$ \\
\hline \multicolumn{3}{|l|}{ Glycine conjugated } \\
\hline Mean & $0 \cdot 1$ & $0 \cdot 1$ \\
\hline Median (range) & $0.09(0.01-0.3)$ & $0.07(0.06-0.2)$ \\
\hline \multicolumn{3}{|l|}{ Taurine conjugated } \\
\hline \multirow{2}{*}{\multicolumn{3}{|c|}{ Sulphated }} \\
\hline & & \\
\hline Mean & 0.07 & 0.02 \\
\hline Median (range) & $0.02(0.002-0.46)$ & $0.01(0.004-0.09)$ \\
\hline \multicolumn{3}{|l|}{ Cholic acid } \\
\hline Mean & & $0 \cdot 3$ \\
\hline Median (range) & $1 \cdot 8(0 \cdot 01-7 \cdot 5)$ & $0.3(0.02-0.6)$ \\
\hline \multicolumn{3}{|l|}{ Chenodeoxycholic acid } \\
\hline $\begin{array}{l}\text { Mean } \\
\text { Median (range) }\end{array}$ & $\begin{array}{l}0.3 \\
0.2(0.02-0.8)\end{array}$ & $\begin{array}{l}0.07 \\
0.05(0.006-0.18)\end{array}$ \\
\hline \multicolumn{3}{|l|}{ Deoxycholic acid } \\
\hline Mean & 1 & 1 \\
\hline Median (range) & $1(0 \cdot 02-2 \cdot 7)$ & $1(0 \cdot 4-1 \cdot 6)$ \\
\hline \multicolumn{3}{|l|}{ Lithocholic acid } \\
\hline Median (range) & $0 \cdot 1(0 \cdot 0-3 \cdot 2)$ & $\begin{array}{l}0.8 \\
0.6(0.5-1.5)\end{array}$ \\
\hline
\end{tabular}

${ }^{\star} \mathrm{p}<0 \cdot 05, \mathrm{tp}<0 \cdot 01$, patients $v$ control subjects. disease in the active phase. Taurine conjugates of bile acids have been reported to induce a proliferative response both in the colonic mucosa (H Ohgaki, personal communication) and in the gastric mucosa ${ }^{33}$ of the rat. The influence of sulphasalazine treatment could not be specifically evaluated because it was impossible for ethical reasons to give healthy children this drug or, alternatively, to stop treatment with the drug since the patients had gone in to remission with sulphasalazine and had no side effects from the treatment. It is unlikely that sulphasalazine might influence the conjugation pattern to explain the differences in this series since no consistent results have been reported on the effect of the drug on the faecal flora in patients with ulcerative colitis or control subjects. West et $a l^{34}$ found a small but significant decrease of total numbers of anaerobes and of enterobacteria during medication. Hazenberg $e t a l^{35}$ reported that patients taking sulphasalazine had an intestinal flora that was completely resistant to sulphapyridine, one of the two components of the drug. No changes of the faecal anaerobes were noted in healthy subjects treated for two weeks with sulphasalazine. ${ }^{36}$

It is also unlikely that methodological factors would explain our results since thin layer chromatography confirmed the accuracy of the separation procedure. Further studies are required to determine whether the observations made in this study are relevant for an aetiological role of bile acids in the risk of colonic cancer in this patient group. A proven relation between an increase ${ }^{*}$ in taurine conjugates and malignancy in clinical practice would have serious consequences since taurine is presently given as supplements both to healthy infants and to patients with gastrointestinal diseases to increase the taurine fraction of bile acids to improve fat absorption.

This work was supported by grants from The Swedish Medical Research Council (4995), Karolinska Institutet, Axel Thielman's Fund, and the Swedish Cancer Society.

1 Aries V, Crowther JS, Drasar BS, Hill MJ, Williams REO Bacteria and the aetiology of cancer of the large bowel. Gut 1969; 10: 334-5.

2 Hill MJ, Crowther JS, Drasar BS, Hawksworth G, Aries V, Williams REO. Bacteria and aetiology of cancer of the large bowel. Lancet 1971; i: 95-100.

3 Reddy BS, Hedges AR, Laakso K, Wynder EL. Metabolic epidemiology of large bowel cancer. Fecal bulk and conepidemiology population. Cancer 1978; 42: 2832-8.

Hill MJ, Drasar BS, Williams REO, Meade TW, Cox AG, Simpson JEP, et al. Faecal bile acids and clostridia in patients with cancer of the large bowel. Lancet 1975; $\mathrm{i}$ : p35-9.

5 Moorhead RJ, Campbell GR, Donaldson JD, McKelvely STD. Relationship between duodenal bile acids and colorectal neoplasia. Gut 1987; 28: 1454-9.

6 Bruce WR. Recent hypotheses for the origin of colon cancer. Cancer Res 1987; 47: 4237-42.

7 Rafter J, Geltner U, Bruce R. Cellular toxicity of human faecal water - possible role in aetiology of colon cancer. Scand $\mathcal{F}$ Gastroenterol 1987; 22: 245-50.

8 Gyde SN, Prior P, Allan RN, Stevens A, Jewell DP, Truelove SC, et al. Colorectal cancer in ulcerative colitis: a cohort study of primary referrals from three centres. Gut 1988; 29: 206-17.

9 Butt JH, Lennard-Jones JE, Richie JK. A practical approach to the risk of cancer in inflammatory bowel disease. Med Clin North Am 1980; 64: 1203-20.

10 Hamilton SR. Colorectal carcinomas in patients with Crohn's disease. Gastroenterology 1985; 89: 398-407.

11 Hill MJ, Melville DM, Lennard-Jones JE, Neale K, Ritchie JR. Faecal bile acids, dysplasia and carcinoma in ulcerative colitis. Lancet 1987; ii: 185-6. 
12 Kirsner JB, Shorter RG. Recent developments in 'nonspecific' inflammatory bowel disease (first of two parts). NEngl f Med 1982; 306: 775-85.

13 Binder V, Both H, Hansen P, Hendriksen C, Kreiner S. TorpPedersen K. Incidence and prevalence of ulcerative colitis and Crohn's disease in the county of Copenhagen 1962 to 1978. Gastroenterology 1982; 83: 563-8.

14 Chong SKF, Bartram C, Campbell CA, Williams CB, Blackshaw AJ, Walker-Smith JA. Chronic inflammatory bowel disease in childhood. $B M \mathcal{F} 1982 ; 284: 101-4$.

15 Breuer N, Dommes P, Tandon R, Goebell H. Isolation and quantification of non-sulphated and sulphated bile acids in faeces. F Clin Chem Clin Biochem 1984; 22: 623-31.

16 Almé B, Bremmelgaard A, Sjövall J, Tomassen P. Analysis of metabolic profiles of bile acids in urine using a lipophilic anion exchanger and computerized gas-liquid chromatography mass-spectrometry. 7 Lipid Res 1977 ; 18: 339-62.

17 Hedenborg G, Norman A. Nature of urinary bile acid conjugates in patients with extrahepatic cholestasis. Scand $\mathcal{F}$ Clin Invest 1984; 44: 725-33.

18 Gänshirt $\mathrm{H}$, Koss FW, Moriantz $\mathrm{K}$. Untersuchungen zur quantitativen Auswertung der Dünnschichtchromatographie. Arzneimittelforschung 1960; 10: 943-7.

19 Rafter JJ, Child P, Anderson AM, Alder R, Eng V, Bruce WR. Cellular toxicity of fecal water depends on diet. Am $\mathcal{F}$ Clin Nutr 1987; 45: 559-63.

20 Dimson SB. Carmine as an index of transit time in children with simple constipation. Arch Dis Child 1970; 45: 232-5.

21 Tanida N, Hikasa Y, Dodo M, Sawada K, Kawaura A, Shimoyama $T$. High concentration and retained amidation of faecal bile acids in patients with active ulcerative colitis. Gastroenterol fpn 1986; 21 : 245-54.

22 Holmqvist L, Andersson H, Rudic N, Åhrén C, Fällström SP. Bile acid malabsorption in children and adolescents with chronic colitis. Scand F Gastroenterol 1986; 21: 87-92.

23 Stadler J, Yeung KS, Furrer R, Marcon N, Himal HS, Bruce WR. Proliferative activity of rectal mucosa and soluble faecal bile acids in patients with normal colons and in patients with colonic polyps or cancer. Cancer Lett 1988; 38: 315-20.
24 Wargovich MJ, Eng VWS, Newmark HL, Bruce WR. Calcium ameliorates the toxic effect of deoxycholic acid on colonic epithelium. Carcinogenesis 1983; 4: 1205-7.

25 Rafter J, Eng VWS, Furrer R, Medline A, Bruce W. Effects of calcium and $\mathrm{pH}$ on the mucosal damage produced by calcium and $\mathrm{pH}$ on the mucosal damage produced

26 Pomare EW, Heaton KW. The effect of cholecystectomy on bile salt metabolism. Gut 1973; 14: 753-62.

27 Almond HR, Vlahcevic Z, Bell C, Gregory DH, Swell C. Bile acid pools, kinetics and biliary lipid composition before and after cholecystectomy. N Engl f Med 1973; 289: 1213-6.

28 Breuer N, Jaekel S, Dommes P, Goebell H. Fecal bile acid pattern in cholecystectomized patients. Dig Dis Sci 1986; 31 : 953-60.

29 Bandettini L, Filipponi F, Romagnoli P. Increase of the mitotic index of colonic mucosa after cholecystectomy. Cancer 1986; 58: 685-7.

30 Hyvärinen H, Partanen S. Association of cholecystectomy with abdominal cancers. Hepatogastroenterology 1987; 34: 87-92.

31 Breuer N, Katschinski B, Mörtl E, Leder L-D, Goebell H. Large bowel cancer risk in cholelithiasis and after cholecystectomy. Digestion 1988; 40: 219-26.

32 Mamianetti A, Cinto $R$, Altolaquirre $D$, Bosicio $O$ Heidenreich A, Salomon M. Relative risk of colorecta cancer after cholecystectomy. A multicenter case-contro study. Int $\mathcal{F}$ Colorectal Dis 1988; 3: 215-8.

33 Ohgaki H, Szestirmay Z, Take M, Sugimura T. Effects of 4 week treatment with gastric carcinogens and enhancing agents on proliferation of gastric mucosa cells in rats. Cancer agents on proliferation
Lett $1989 ; 46: 117-22$.

34 West B, Lendrum R, Hill MJ, Walker G. Effects of sulphasalazine (Salazopyrin) on faecal flora in patients with inflam matory bowel disease. Gut 1974;15:960-5.

35 Hazenberg MP, Bakker M, Both-Patoir HC, Ruseler-van Embden JGH, Schröder AM. Effect of sulphasalazine on the human intestinal flora. F Appl Bacteriol 1982; 52: 103-7.

36 Krook A. Effect of metronidazole and sulphasalazine on the normal human faecal flora. Scand 7 Gastroenterol 1981; 16: $587-92$ 